\title{
AOR
}

Selected Papers of \#AolR2020: The $21^{\text {st }}$ Annual Conference of the Association of Internet Researchers Virtual Event / 27-31 October 2020

\section{PAYING RESPECTS, STREAMING AFFECT: U.S. ELECTION DAY 2016 AT SUSAN B. ANTHONY'S GRAVESITE}

\author{
Chelsea Butkowski \\ Cornell University
}

On U.S. Election Day 2016, the typically quiet footpaths of Mount Hope Cemetery in Rochester, NY filled with thousands of people, lined up together with yellow roses, American flags, and their smartphones in tow. They were waiting to visit the grave of the famed women's suffragist Susan B. Anthony, buried there over a century prior. The 2016 election marked the first time in U.S. history that a major political party nominated a woman presidential candidate, Hilary Clinton. After voting in the election, local women commemorated the milestone and Anthony's suffrage activism by visiting her grave in unprecedented droves. Beyond the crowd that gathered at the cemetery, however, another much larger crowd gathered to witness the event online.

One of Rochester's local news stations, WROC-TV, posted a thirteen-hour livestream of the gravesite and its visitors to Facebook Live. Yet, the broadcast's reach extended far outside of WROC-TV's typical local base. Accruing millions of views, thousands of comments, and write-ups by dozens of news outlets on Election Day, the livestream became a national spectacle. As networked broadcasts, livestreams combine live video with a real-time comment feed, allowing viewers to interact with one another and the broadcaster as the event unfolds (Taylor, 2018). This particular stream centers on Anthony's gravestone piled with flowers and plastered with "I voted" stickers as thousands of people "pay their respects," posing for photos alongside it. In the liminal hours before election results materialized, viewers marveled at the lines of people assembled as far as the camera could see, cried as women visited the grave with their mothers and daughters, and debated the election among themselves.

Though news is closely tied to building collective memory (Kitch, 2008), digital media systems and social networking sites have developed complex relationships with death and commemoration (e.g., Gibson \& Jones, 2012). Social media platforms can facilitate the construction and framing of shared personal and collective histories (Humphreys,

Suggested Citation (APA): Butkowski , C. (2020, October). Paying Respects, Streaming Affect: Election Day at Susan B. Anthony's Gravesite. Paper presented at AolR 2020: The $21^{\text {st }}$ Annual Conference of the Association of Internet Researchers. Virtual Event: AolR. Retrieved from http://spir.aoir.org. 
2018), but navigating their affordances has also resulted in the development of distinctive social norms surrounding digital affect and memorialization (e.g., Gianxoglou \& Döveling, 2018). Although existing research has begun to examine how "ordinary" social media users negotiate such norms, it has rarely explored how media creators locate and represent themselves within broad historical and political narratives.

The 2016 gravesite livestream records and reconstitutes the ceremony of revisiting Susan B. Anthony's grave, integrating the perspectives of political institutions, broadcasters, in-person visitors, and networked audience members. I study it by drawing from Frosh and Pinchevski's (2018) framework of media witnessing, which builds a digital perspective onto the ritual broadcast of televised media events (Dayan \& Katz, 1992). The stream is fueled and framed by a collective memory of women's suffrage and Anthony's life. It shares a particular liberal vision of U.S. American women's history and future, which was later left unfulfilled when Clinton lost the election. Livestreaming is also a technically distinct medium for housing affective discourse. Though it is rooted in videogaming, it has become common to stream funerals, news events, and acts of injustice (Martineau, 2019), but despite its growing breadth, it is uncommon to study livestreaming outside of gaming cultures. Therefore, I ask the following research questions. First, how do the media actors involved in the 2016 gravesite livestream use commemoration as a means for self-representation? Second, how do the affordances of the livestreaming medium shape these practices and the collective memory that drives them?

\section{Method}

I conducted a textual analysis of the video and comment content of the WROC-TV livestream of Susan B. Anthony's gravesite on November 8, 2016. This includes both the video feed and real-time comment feed, which remain publicly available today on the WROC-TV's Facebook page. After watching two full videos to immerse myself in the material, I engaged in an iterative coding process to analyze the audiovisual and textual aspects of the entire 13.5-hour livestream.

\section{Analysis}

Four media actors differently shaped the gravesite livestream by contributing to its content and interacting with one another. In line with traditions of media events and media witnessing, I examine each of them. I argue that the livestream enabled each of these actors to represent political selfhoods through commemorative acts.

First, the Rochester mayor's office systematized visiting the gravesite as an Election Day media event. Though paying tribute to Anthony's grave was previously a small local tradition, the office used advertising, a staff of volunteer photographers, and extended cemetery hours to attract and control a historic crowd in 2016.

Second, the gravesite visitors, who were mostly women, modeled norms of visual selfrepresentation as the main subjects of the livestream. When each of them reached the front of the line, they almost invariably handed their phone to a volunteer and posed for a photo with the gravestone, likely to be posted to their social media accounts. Akin to both voting selfies and funeral selfies (Meese et al., 2015), shared practices surrounding gravestone photo etiquette developed over the course of the stream. 
Third, John Kucko, the journalist who narrated and filmed the entirety of the stream, controlled the broadcast itself. While filming and narrating, he tied national and local stories of political women together with his own autobiography as a male media professional. The nature of the live broadcast required him to repeat himself frequently and enabled him to tighten his narrative as viewers rapidly transitioned. Among his most repeated narratives were Susan B. Anthony's life story, descriptions of the event as "spectacular" and "non-partisan," the visitors as "well-behaved," and the stream as the height of his "long journalistic career."

Fourth, thousands of commenters witnessed the stream and conversed directly with Kucko and one another. Many commenters sought information, but others told personal stories connecting them to Anthony, Clinton, and the election.

\section{Conclusion}

Within one contained case, the 2016 gravesite livestream illustrates how various actors can co-construct collective memory through digital means. I argue that these actors represent themselves within shared narratives of ongoing and historical political events through live interaction with one another. Ultimately, I suggest that in commemorating women's historical political action, these self-representational narratives present livestream creators, viewers, subjects as political actors. It also suggests the political potential of the medium itself.

\section{References}

Dayan, D., \& Katz, E. (1992). Media events: The live broadcasting of history. Cambridge: Harvard University Press.

Frosh, P., \& Pinchevski, A. (2018). Media and events after Media events. Media, Culture, \& Society, 40, 135-138. doi:10.1177/0163443717726007

Gibson, P. L., \& Jones, S. (2012). Remediation and remembrance: "Dancing Auschwitz" collective memory and new media. ESSACHESS: Journal for Communication Studies, 5(2), 107-131. Retrieved from http://www.essachess.com/index.php/jcs/article/view/171

Humphreys, L. (2018). The qualified self: Social media and the accounting of everyday life. Cambridge: MIT Press.

Kitch, C. (2008). Placing journalism inside memory-and memory studies. Memory Studies, 1(3), 311-320. doi:10.1177/17506980080937961

Martineau, P. (2019, July 30). Now even funerals are livestreamed-and families are grateful. Wired. Retrieved from https://www.wired.com/story/funerals-livestreamedfamilies-grateful/

Meese, J. et al. (2015). Selfies at funerals: Mourning and presencing on social media platforms. International Journal of Communication, 9, 1818-1831. Retrieved from https://ijoc.org/index.php/ijoc/article/viewFile/3154/1402 
Taylor, T. L. (2018). Watch me play: Twitch and the rise of game livestreaming.

Princeton: Princeton University Press. 